\title{
Nosocomial Leuconostoc Pseudomesenteroides Meningitis: A Case Report and Review of the Literature
}

\author{
Özlem Taşkapılıoğlu¹, Aslı Bahar ${ }^{1}$, Emel Yılmaz², Mustafa Bakar ${ }^{1}$ \\ ${ }^{1}$ Department of Neurology, School of Medicine, Uludağ University, Bursa, Turkey \\ ${ }^{2}$ Department of Infectious Diseases and Clinical Microbiology, School of Medicine,Uludağ University, Bursa, Turkey
}

\begin{abstract}
Leuconostoc spp, a member of the Streptococci family, was found to cause infection in humans in 1985 . These infections have been reported in patients who had received vancomycin to treat their underlying diseases.

Nosocomial meningitis caused by Leuconostoc spp. was diagnosed in our patient. An extraventricular drainage system catheter was used due to the presence of a thalamic hematoma with ventricular extension. Central nervous system infections due to Leuconostoc spp. are rare. To our knowledge, our case is the sixth case worldwide and the second case reported from Turkey. This case is reported here to draw attention to a rare infectious agent
\end{abstract} with a high mortality risk.

Key Words: Chloramphenicol, leuconostoc, meningitis, nosocomial

Received: 09.03.2009

Accepted: 07.07.2009

Leuconostoc spp. members of the Streptococcaceae family, are nonmotile, facultative anaerobic gram-positive cocci that are naturally resistant to vancomycin (1). The first case with Leuconostoc spp. as a potential cause of human infection was recorded in 1985, after which these organisms were recognized as potential pathogens $(2,3)$. Infections with Leuconostoc spp. bacteria usually affect patients with an underlying disease, with venous catheters, or subjects previously treated with vancomycin (2).

Here, we report a patient with nosocomial meningitis due to Leuconostoc spp. An extraventricular drainage system (EVDS) catheter was used because he had a thalamic hematoma with ventricular extension. Central nervous system (CNS) infections due to Leuconostoc spp. are rare. Our case is the sixth case worldwide and the second case reported from Turkey. We discuss the case in the context of the literature.

\section{Case Report}

A 52-year-old male was admitted to the emergency department with the complaint of altered mental status. He had a Glasgow Coma Scale score of 13 and his neurological examination revealed confusion, disorientation, limited cooperation, and first motor neuron type left hemiparesis involving the face. His cranial computed tomography (CT) demonstrated a $4 \mathrm{~cm}$ thalamic hematoma in the right cerebral hemisphere, which had collapsed into both the right lateral ventricle and the $3^{\text {rd }}$ and $4^{\text {th }}$ ventricles (Figure $1 \mathrm{~A}$ ). His medical history revealed hypertension. Neurological parameters were closely monitored with EVDS in the neurological intensive care unit (Figure 1B). The control cranial CT performed on the $19^{\text {th }}$ day after admission showed resorption of the hemorrhage and the EVDS catheter was removed (Figure $1 \mathrm{C}$ ). The CSF culture performed on the $16^{\text {th }}$ day after admission ( 3 days prior to catheter removal) was negative. On the $28^{\text {th }}$ day after admission, he had new onset fever $\left(38.5^{\circ} \mathrm{C}\right)$ and headache. $\mathrm{He}$ was lethargic, but other system examinations were normal. Laboratory findings revealed a leukocyte count of 8,600/ $\mathrm{mm}^{3}, 215,000$ platelets $/ \mathrm{mm}^{3}$, aspartate transaminase (AST) of $68 \mathrm{lU} / \mathrm{ml}$, and alanine transaminase (ALT) of $179 \mathrm{lU} / \mathrm{ml}$. Other laboratory findings were unremarkable. A lumbar puncture (LP) was performed to eliminate nosocomial meningitis as a possible fever focus in the patient. Microscopic examination of the CSF revealed 180 leucocytes $/ \mathrm{mm}^{3}$ (70\% polymorphonuclear leukocytes, 30\% lymphocytes) and biochemical tests indicated elevated protein $(70 \mathrm{mg} / \mathrm{dl})$ and normal glucose (53 $\mathrm{mg} / \mathrm{dl}$; accompanying serum glucose, $118 \mathrm{mg} / \mathrm{dl}$ ). There was no microorganism on the CSF gram stain. Empirical therapy with intravenous vancomycin ( $1 \mathrm{~g} / 12 \mathrm{~h}$ ) and meropenem (2 $\mathrm{g} / 8 \mathrm{~h}$ ) was started with the putative diagnosis of nosocomial meningitis. The CSF and blood cultures obtained during the fever episode produced Leuconostoc pseudomesenteroides with a negative EVDS catheter culture. Leuconostoc pseudomesenteroides was confirmed using the Phoenix System ${ }^{\mathrm{TM}}$ (NMIC/ID-5 panel, Becton Dickson, Sparks, MD, USA). The isolate was also determined to be sensitive to amoxicillin, levofloxacin, rifampicine, and tetracycline. Antimicrobial susceptibility tests were performed using both the Phoenix 
System ${ }^{\mathrm{TM}}$ and the Kirby-Bauer disc diffusion method, which was made and set up according to Clinical and Laboratory Standards Institute standard protocol (4). Intravenous vancomycin and meropenem were replaced with intravenous chloramphenicol $(1 \mathrm{~g} / 8 \mathrm{~h})$ and ciprofloxacin $(400 \mathrm{mg} / 12 \mathrm{~h})$ because of the natural resistance of the bacteria. Repeated LPs were performed on days $5,15,18$, and 30 of the therapeutic regimen of chloramphenicol and ciprofloxacin. The microscopic examination of the CSF obtained from these LPs revealed no cells and the CSF was negative for culture only in the LPS performed on the $18^{\text {th }}$ and $30^{\text {th }}$ days of the treatment. Intravenous chloramphenicol was stopped on the $19^{\text {th }}$ day of this treatment. The patient was discharged with stable vital signs and motor neuron-type left hemiparesis of $4 / 5$ muscle strength.

\section{Discussion}

Bacteremia, meningitis, breast abscess, peritonitis, abdominal and brain abscesses, and odontoid and urinary tract infections with Leuconostoc spp. have been reported $(2,5)$. In the literature, there are six cases, including ours, of CNS infection due to Leuconostoc spp. Four of these were diagnosed as meningitis, one was a brain abscess, and the other one was nosocomial ventriculitis. Clinical features of the cases are summarized in Table 1 (3, 6-9).

Leuconostoc spp. usually found on vegetables and food products, are not a member of the usual human flora, but have been isolated from vaginal and stool samples (3). The source of the isolate has been debated in the literature since these organisms are not considered part of the normal human flora. Some have suggested skin as a possible portal; others have raised the possibility of access to the bloodstream through the gastrointestinal tract (GIT) (1). Nosocomial transmission may be via contaminated hands; urinary catheterization may also play a role in the development of Leuconostoc septicemia $(2,10)$. Three of the reported cases support the nosocomial transmission theory because they developed infection after an invasive intervention involving the CNS; whereas, one of the cases that developed infection after colostomy supports the theory of translocation from the GIT (7-9).

Leuconostoc infections occur more frequently in patients being treated for underlying diseases with vancomycin therapy, although these infections have also been documented in otherwise healthy patients $(2,6)$. Our patient had not received vancomycin therapy before the detection of Leuconostoc spp. as shown by the negative CSF and blood cultures obtained before treatment. Three of the six cases with prior steroid therapy before infection differ greatly from the remaining cases $(3,9)$. Prior treatment with steroids seems to predispose patients to CNS infections with Leuconostoc spp. (3).

Penicillin is an antibiotic commonly used to treat Leuconostoc spp. infections. In catheter-associated infections, removal of the catheter is the priority (1). Identification of the bacteria is very important because of its resistance to vancomycin (1). We preferred intravenous chloramphenicol to treat our patient because of its good CNS penetration, its reported success in the treatment of Leuconostoc meningitis, and the sensitivity of the bacteria to chloramphenicol (6). Cephalospo-

Table 1. Clinical features of the central nervous system infections due to Leuconostoc $\operatorname{spp}(3,6-9)$

\begin{tabular}{|c|c|c|c|c|c|c|c|c|}
\hline $\begin{array}{l}\text { Reported } \\
\text { Date }\end{array}$ & Age & Sex & $\begin{array}{l}\text { Symptoms/ } \\
\text { Findings }\end{array}$ & Diagnosis & $\begin{array}{l}\text { Invasive } \\
\text { Intervention }\end{array}$ & $\begin{array}{l}\text { Prior } \\
\text { Steroid } \\
\text { Use }\end{array}$ & $\begin{array}{c}\text { Treatment } \\
\text { (Duration-Day) }\end{array}$ & Outcome \\
\hline $1987^{6}$ & $16 y$ & $\mathrm{~F}$ & $\begin{array}{c}\text { Altered mental status, } \\
\text { headache, vomiting, neck } \\
\text { stiffness, Kernig's sign, } \\
\text { Brudzinski's sign, leukocytosis }\end{array}$ & Meningitis & None & No & $\mathrm{P}(14)+\mathrm{CHL}(5)$ & Recovery \\
\hline $1990^{7}$ & $1 \mathrm{mo}$ & $F$ & $\begin{array}{l}\text { Irritability, increased tonus, } \\
\text { brisk reflexes, bulging } \\
\text { fontanella, anemia, } \\
\text { leukocytosis }\end{array}$ & Meningitis & Colostomy & No & $\begin{array}{c}\mathrm{P}(\mathrm{NK})+\mathrm{CFX}(\mathrm{NK}) ; \\
\mathrm{P}(\mathrm{NK})+\mathrm{CFX}(\mathrm{NK})+ \\
\mathrm{CHL}(\mathrm{NK})+ \\
\text { GEN(NK) (IVT) }\end{array}$ & Death \\
\hline $2003^{8}$ & $50 y$ & $M$ & $\begin{array}{l}\text { Altered mental status, } \\
\text { fever, leukocytosis }\end{array}$ & Ventriculitis & $\begin{array}{l}\text { Ventricular } \\
\text { shunt }\end{array}$ & No & $\begin{array}{l}\text { VA(NK)+CFX(NK); } \\
\text { CFX(NK)+LIN(NK); } \\
\text { MEM(NK); GAT(NK); } \\
\text { GAT(14)+P(14) }\end{array}$ & Recovery \\
\hline $2006^{3}$ & $61 \mathrm{y}$ & $\mathrm{F}$ & $\begin{array}{l}\text { Hemiparesis, headache, } \\
\text { anemia }\end{array}$ & Brain abscess & None & Yes & $\begin{array}{c}\text { CFX(NK); } \\
\text { P(42)+AMP(42); } \\
\text { AMX (42) }\end{array}$ & Recovery \\
\hline $2008^{9}$ & $57 y$ & $F$ & $\begin{array}{l}\text { Altered mental } \\
\text { status, fever }\end{array}$ & Meningitis & LP & Yes & $\begin{array}{c}\mathrm{CFT}(\mathrm{NK})+\mathrm{VA}(\mathrm{NK}) ; \\
\mathrm{LIN}(14)\end{array}$ & Recovery \\
\hline 2009 & $52 y$ & $M$ & $\begin{array}{l}\text { Altered mental } \\
\text { status, fever }\end{array}$ & Meningitis & EVDS & Yes & $\begin{array}{l}\text { VA(7)+MEM(7) } \\
\text { CHL(14)+CIP(10) }\end{array}$ & Recovery \\
\hline
\end{tabular}

F: Female, M: Male, y: Year, mo: Month, LP: Lumbar puncture, EVDS: Extraventricular drainage system, IVT: Intraventricular, NK: Not known, P: Penicillin, CHL: Chloramphenicol, CFX: Cefotaxime, GEN: Gentamicin, VA: Vancomycin, LIN: Linezolid, MEM: meropenem, GAT: Gatifloxacin, AMP: Ampicillin, AMX: Amoxicillin, CFT: Ceftazidime, CIP: Ciprofloxacin 

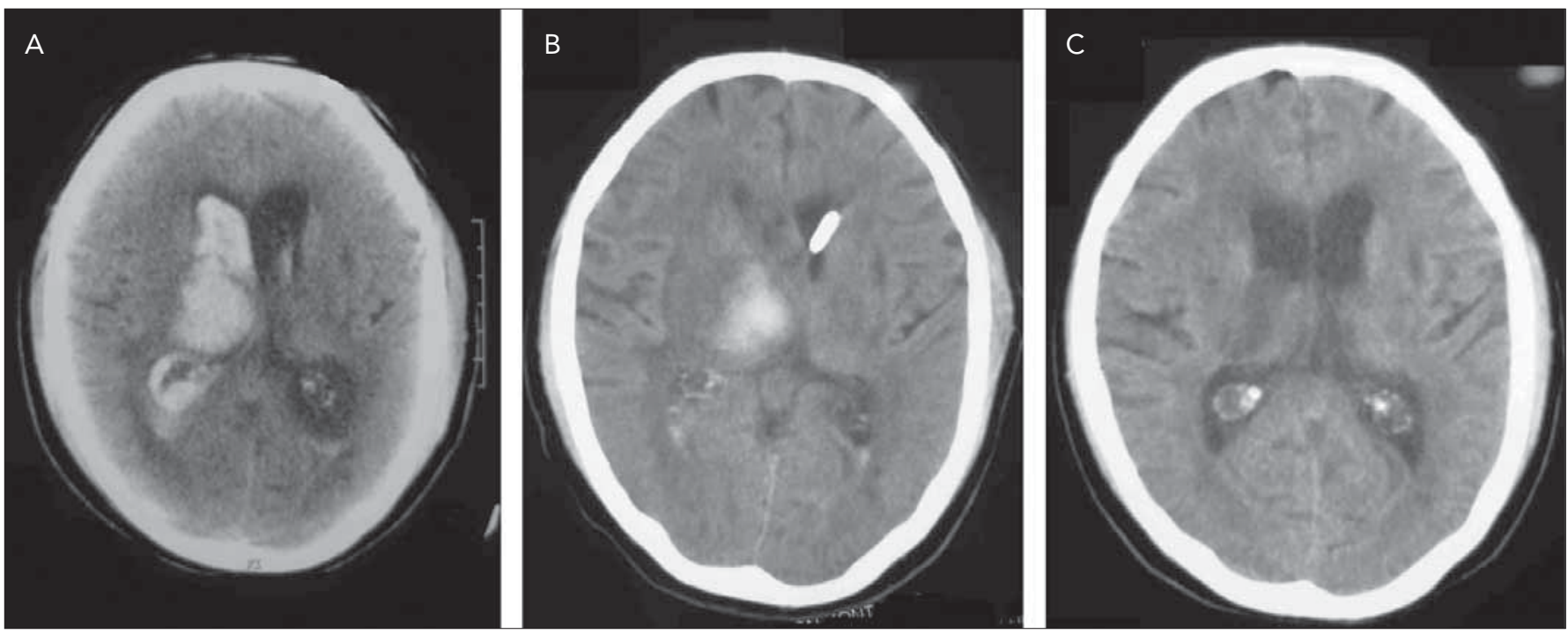

Figure 1. The right thalamic hematoma (A) seen at admission of the patient, and the following cranial computed tomography findings after placement of the EVDS catheter (B) and on the 19th day after admission (C).

rin, gentamicin gatifloxacin, ampicillin, amoxicillin and linezolid are also options for a successful treatment, as stated in the literature $(3,7-9)$.

Infections with Leuconostoc spp. are rare. We report our case as the sixth case worldwide and the second case from Turkey in order to raise awareness of CNS infection with Leuconostoc spp. that may have a high mortality and morbidity risk.

\section{Conflict of Interest}

No conflict of interest was declared by the authors.

\section{References}

1. Dhodapkar Km, Henry Nk. Leuconostoc Bacteremia In An Infant With Short-Gut Syndrome: Case Report And Literature Review. Mayo Clin Proc 1996;71:1171-4. [CrossRef]

2. Taneja N, Rani P, Emmanuel R, Khudaier By, Sharma Sk, Tewari R, Sharma M. Nosocomial Urinary Tract Infection Due To Leuconostoc Mesenteroides At A Tertiary Care Centre In North India. Indian J Med Res 2005;122:178-9. [CrossRef]

3. Albanese A, Spanu T, Sali M, Novegno F, D'inzeo T, Santangelo R, Mangiola A, Anile C, Fadda G. Molecular Identification of Leuconostoc Mesenteroides As A Cause Of Brain Abscess In An Immunocompromised Patient. J Clin Microbiol 2006;44:3044-5. [CrossRef]

4. CLSI. 2008. Methods For Dilution Antimicrobial Susceptibility Test For Bacteria That Grow Aerobically; Approved Standard, Eighth Ed. M07-A8. Clsi, Wayne, Pa.

5. Wenocur Hs, Smith Ma, Vellozzi Em, Shapiro J, Isenberg Hd. Odontogenic Infection Secondary To Leuconostoc Species. J Clin Microbiol 1988;26:1893-4.

6. Coovadia Ym, Solwa Z, Van Den Ende J. Meningitis Caused By Vancomycin-Resistant Leuconostoc Sp. J Clin Microbiol 1987;25:1784-5

7. Friedland Ir, Snipelisky M, Khoosal M. Meningitis In A Neonate Caused By Leuconostoc Sp. J Clin Microbiol 1990;28:2125-6.

8. Deye G, Lewis J, Patterson J, Jorgensen J. A Case Of Leuconostoc Ventriculitis With Resistance To Carbapenem Antibiotics. Clin Infect Dis 2003;37:869-70.

9. Hatipoğlu Ca, Yildiz E, Köktekir E, Ipekkan K, Karakoç Ea, Demiröz Ap. A Case Of Vancomycin Resistant Leuconostoc Meningitis. Mikrobiyol Bul 2008;42:695-9.

10. Muttaiyah S, Ritchie S, Upton A, Roberts S. Clinical Parameters Do Not Predict Infection In Patients With External Ventricular Drains: A Retrospective Observational Study Of Daily Cerebrospinal Fluid Analysis. J Clin Microbiol 2008;57:207-9. [CrossRef] 